\title{
Perception of Fisherman and Government Officer on Policy Implementation of Cantrang Prohibition in Lampung Bay
}

\author{
Indra Gumay Febryano ${ }^{1, *}$, Debi Hardian ${ }^{1}$, Supono Supono ${ }^{1}$, Abdullah Aman \\ Damai ${ }^{1}$, Endang L. Widiastuti ${ }^{1}$, Novriyanti Novriyanti ${ }^{1}$ \\ ${ }^{I}$ Graduate School of Coastal and Marine Zone Management, Universitas Lampung, Bandar Lampung, Indonesia \\ *Corresponding author.Email: indragumay@yahoo.com
}

\begin{abstract}
The policy to prohibit cantrang fishing gear is intended to prevent excessive exploitation of fish resources, environmental degradation and conflicts between fisherman, but fisherman and government officers' perceptions of the policy are not the same. The purpose of this study was to analyze the perceptions of fisherman and government officer on the implementation of the prohibition of cantrang fishing gear policy in Lampung Bay. Data collection was carried out by interviewing 30 fishermen and 30 government officers. The data obtained were analyzed using a Likert Scale and polarized between the perceptions of fisherman and government officers. The results showed that fisherman's perceptions of the successful implementation of cantrang fishing gear prohibition policies were influenced by the attitude of the implementers and the inaccurate standards and policy targets/policy size and objectives. This is following the fisherman's refusal to prohibit cantrang fishing gear policy by continuing to operationalize cantrang fishing gear. The perception of the government apparatus the high influence of the economic, social and political environment influences the successful implementation of cantrang fishing gear prohibition policies. Perceptions between fisherman and government officers who are not in harmony cause the failure of the cantrang fishing gear prohibition policy in Lampung Bay. Thus it is necessary to review the policy of prohibiting fishing gear cantrang and strategic steps for its implementation.
\end{abstract}

Keywords: policy, policy implementation, cantrang, perception, Lampung Bay

\section{INTRODUCTION}

The potential of marine and fisheries in Indonesia can improve the economy of fisherman even though in reality it has not been able to reduce the poverty level of coastal communities [1-3]. One of the utilization of fisheries resources is done by fishing using various kinds of fishing gear that have different productivity and fishing areas. The level of productivity of fishing gear can affect the level of welfare of fisherman [4-6].

One of the fishing gear favoured by fisherman is cantrang fishing gear which is considered to have high productivity and maintenance of fishing gear is relatively easy. Cantrang is net-shaped fishing gear, has wings, body, and pockets, does not use a net opening, capture area in a flat-water area with a muddy or sandy substrate, not rocky [7-8]. But, in the course of fishing gear cantrang considered to cause degradation and destructive to the environment and fish resources. At present, the use of marine wealth is feared to accelerate the decline in the carrying capacity of fish and ecosystem resources. According to FAO in [2], 90\% of the world's fisheries stocks are in an alarming condition, $61 \%$ have experienced fully exploited and the remaining $29 \%$ are overexploited. 
Utilization of resources must be accompanied by policies to avoid damage to the environment, the decline in fish resources and ecosystems [9-12]. The policy is deliberately done to solve a particular problem [13]. Policy implementation is one that is identified within the scope of the policy process [14]. Analysis and implementation are crucial stages in the policymaking process [15].

To overcome the decline in fish and environmental resources by cantrang fishing gear, the government has established a policy prohibiting cantrang through the Minister of Maritime Affairs and Fisheries Republic of Indonesia Regulation Number: $71 /$ Permen-KP/2016. This policy was rejected by fisherman so that it was deemed unsuccessful in its implementation. The response of fisherman to the prohibition of cantrang fishing gear is based on the perception of each fisherman. Perception is the process by which the brain interprets sensory impressions, selective attention, filters out irrelevant stimuli, directives for someone to behave, views responding to the information around them [16]. The purpose of this study was to analyze the perceptions of fisherman and government officers on the policy implementation of cantrang prohibition in Lampung Bay.

\section{METHOD}

The research location is in Lampung Bay with the loading/unloading port of the cantrang ship at the Lempasing Coastal Fishery Port, Bandar Lampung City. The study was conducted in January-June 2019. Data were collected through interviews using questionnaires, observations, and documentation studies. Interviews were conducted with 30 fishermen (ship owners, ship management, skipper, head of engine room, and shipmen) and 30 government officers.

Data on the perception of fisherman and government officers were analyzed using a Likert Scale of standards, policy targets /measures, and policy objectives; policy sources; characteristics or nature of the implementing agency /agency; communication between organizations related to implementation activities; the attitude of the implementers; and the economic, social and political environment of implementing the prohibiting fishing gear policy. Likert Scale is used to measure the attitudes, opinions, and perceptions of a person or group of people about social phenomena [17]. The questionnaire contains a perception assessment with a Likert Scale where five alternative answers. Further analysis was carried out using the polarization graph to study the polarization of perceptions among fisherman and government officers.
Table 1. Likert Scale that used on the perception of fisherman and government officers.

\begin{tabular}{ll}
\hline Statement & Value \\
\hline Strongly disagree & 1 \\
Disagree & 2 \\
Average & 3 \\
Agree & 4 \\
Strongly Agree & 5 \\
\hline
\end{tabular}

The calculation formula used in Likert scale data analysis in Microsoft Excel is:

1. The Likert scale calculation formula uses 5 alternative answers

$$
\begin{aligned}
& \mathrm{NL}=\sum(\mathrm{n} 1 \times 1)+\left(\mathrm{n}_{2} \times 2\right)+\ldots \ldots+\left(\mathrm{n}_{\mathrm{n}} \times \mathrm{n}\right) \\
& \text { where: } \\
& \mathrm{NL}=\text { Likert scale scoring value } \\
& \mathrm{n}=\text { Number of answer scores (alternative Likert } \\
& \quad \text { score to } 5)
\end{aligned}
$$

2. The average calculation formula for each aspect of the question

$\mathrm{Q}=\mathrm{NL} / 30$

where:

$\mathrm{Q}=$ Average of each aspect of question

$\mathrm{NL}=$ Likert scale scoring value

$30=$ number of respondent samples

3. The final grade formula for each aspect

$$
\mathrm{NA}=\mathrm{Q} 1+\mathrm{Q} 2+\mathrm{Q} 3+\mathrm{Q} 4+\mathrm{Q} 5
$$

where:

$$
\begin{aligned}
\mathrm{NA}= & \text { Final score } \\
\mathrm{Q}= & \text { Average of reach aspect of the question } \\
& (\text { Likert uses a scale of 5) }
\end{aligned}
$$

\section{RESULTS AND DISCUSSION}

\subsection{General Description of the Location}

The Lampung Bay coastal area is administratively located in Bandar Lampung City, Pesawaran Regency, and South Lampung Regency. The area of water in this region is 161,178 ha. The fishing fleet operating in Lampung Bay is approaching 2,500 units, with various types and sizes of ships, both motorized and nonmotorized. The type of small motorized vessels $(<5$ tons and 5-10 tons) is the type of boat that is mostly operated by fisherman because the Lampung Bay fisherman are dominated by small fisherman (artisanal) and generally go to sea in just one day (one-day fishing). Larger vessels (10-20 tons and $>20$ tons) are groups of fishermen operating outside the Gulf of Lampung (Semangka Bay, 
Sunda Strait, West and East waters of Lampung, or to the Java Sea), and the coastal areas of the Gulf Lampung are only a place to land and live (fishing base).

In 2019 cantrang vessels operating around Lampung Bay will be under 30 GT with a total of 28 units. Usually manned by a skipper and head of the machine room, with total crew ranging from 10-15 people per ship. They carry out loading and unloading activities at the Lempasing Beach Fishing Port, Bandar Lampung City. Fish catch does not go into the fish auction place (Tempat Pelelangan Ikan/TPI) but is directly sold in unloading docks so that the capture fisheries production data is not recorded and there is no revenue or government. On the other hand, if fish caught by cantrang at auction at TPI will become legality for the existence of cantrang vessels, while regulations for prohibiting cantrang fishing gear have been established.

\subsection{Fisherman's Attitudes in The Fisherman Insurance program}

Perceptions between fisherman and the government are not the same in understanding and implementing cantrang prohibition policies (Table 1). The polarization graph shows the perceptions between fisherman and government officers are not aligned or not the same as Figure 1. The most opposing opinion between the two is the attitude of the implementers and the economic, social, and political environment. From six variables, none of the fisherman and government perceptions were the same.

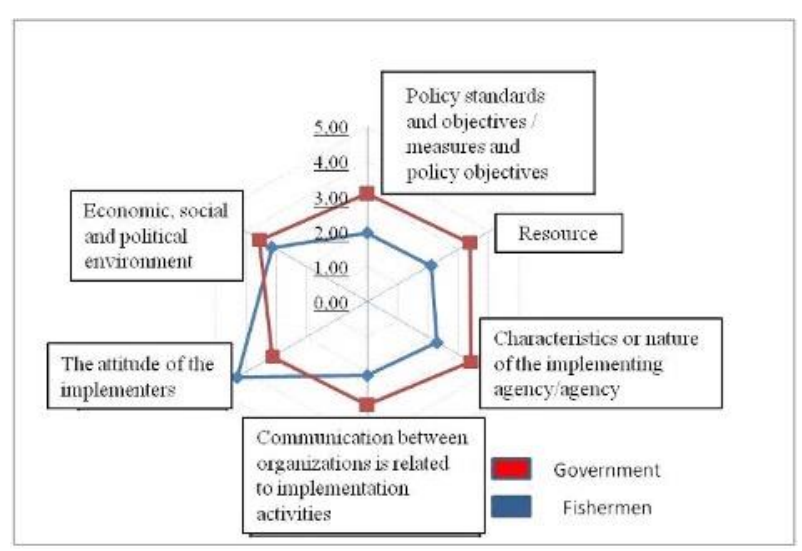

Figure 1 The polarization of perception of fisherman and government officers.

Some differences in perception between fisherman and government officers can be described based on the following variables:

1. Policy standards and objectives /measures and policy objectives;

Fisherman disagree with policy standards and targets/measures and policy objectives, arguing that cantrang fishing gear is not degradative and destructive to the environment and fish resources because cantrang fishing gear is operated on mud or sand substrates, not on rocks/coral reefs. While the government's goal to prohibit the use of cantrang fishing gear is to protect fish resources and the environment. The size and objectives of the policy according to the fisherman are unrealistic and do not consider the sociocultural at the policy implementation level (fisherman). Policies that are too ideal (utopian) will be difficult to realize.

Table 2. Perceptions of fisherman and government officers.

\begin{tabular}{|c|c|c|c|}
\hline \multirow{2}{*}{\multicolumn{2}{|c|}{ Research Variables }} & \multicolumn{2}{|c|}{ Average Score } \\
\hline & & Fisherman & Government \\
\hline 1 & $\begin{array}{l}\text { Policy standards and } \\
\text { objectives/measures } \\
\text { and policy objectives }\end{array}$ & 2 & 3 \\
\hline 2 & Resources & 2 & 3 \\
\hline 3 & $\begin{array}{l}\text { Characteristics or } \\
\text { nature of the } \\
\text { implementing } \\
\text { agency/agency }\end{array}$ & 2 & 3 \\
\hline 4 & $\begin{array}{l}\text { Communication } \\
\text { between organizations } \\
\text { is related to } \\
\text { implementation } \\
\text { activities }\end{array}$ & 2 & 3 \\
\hline 5 & $\begin{array}{l}\text { The attitude of the } \\
\text { implementers }\end{array}$ & 4 & 3 \\
\hline 6 & $\begin{array}{l}\text { The economic, social, } \\
\text { and political } \\
\text { environment }\end{array}$ & 3 & 4 \\
\hline
\end{tabular}

2. Resource;

Fisherman do not agree with the resources owned by the government for the implementation of policies in the field. Human resources, financial resources and time are not sufficient to implement cantrang fishing gear prohibition policies. While the government apparatus is neutral towards the resource variable.

3. Characteristics or nature of the implementing agency/agency;

Related to the characteristics or nature of the implementing agency/agency, according to the fisherman, they also do not agree with the current conditions in which implementing agents (formal or informal) involved in implementing policies are required to be strict and disciplined, although in other contexts democratic and persuasive attitudes are needed. According to fisherman, currently, the implementing agency (government) is not strict in carrying out the Standard Operating 
Procedures (SOPs) that are made so that there is a difference in treatment in the field. The facts on the ground show that the government does not act firmly and take legal action against fisherman who still use cantrang fishing gear, even in some areas it is permissible to use cantrang fishing gear (Central and East Java).

4. Communication between organizations is related to implementation activities;

Regarding communication between organizations related to the current implementation activities, fisherman do not agree because of the lack of socialization and other forms of communication conveyed by the government regarding the prohibition of fishing gear cantrang to fisherman. While the perception of government officers is neutral in assessing the implementation of communication. Communication is needed in the framework of delivering information to policy recipients starting from the standards, objectives, policy objectives and others. The better coordination and communication between the implementing agent and the recipient of the policy, the smaller the error, and vice versa.

5. The attitude of the implementers;

According to fisherman, the attitude of the implementers that most influences the successful implementation of a policy. While the government officers assess neutral towards the variable attitude of the implementers. This is consistent with the facts on the ground where the attitude of fisherman who reject the prohibition of fishing gear cantrang policy causes the implementation of the policy to fail. The refusal of fisherman is shown by the still operating of cantrang vessels in the Gulf of Lampung and its surroundings, rejecting replacement fishing gear and conducting mass demonstration activities asking that the prohibition of cantrang fishing gear be lifted.

The attitude of the implementers is decisive in the successful implementation of a policy. An attitude that refuses to make a major contribution to the failure of implementing cantrang fishing gear prohibition policies in fishing communities. This can happen because the contents of the policy are considered "top-down" which is very possible decision-makers (the government) do not understand and do not touch the needs, desires or problems that must be resolved. The attitude of the implementers is influenced by his views on policy and how to see the influence of the policy on personal or group interests. Policy implementation begins with filtering through the perception of the implementer within the limits where the policy is implemented. Three things influence the implementation of policies in implementing policy, namely: a) knowledge, understanding and deepening; b) the direction of the response whether to accept, neutral or reject; c) the intensity of the policy.

6. The economic, social, and political environment; Fisherman's perception of the influence of the economic, social, and political environment on the implementation of the policy of prohibiting moderate/neutral fishing gear. This means that the economic, social and political environment does not influence the implementation of cantrang fishing gear prohibition policies today because economically fisherman still earn income from cantrang fishing gear that they operate even though it has been banned by the government. The government apparatus believes that the economic, social, and political environment influences the successful implementation of the prohibition of fishing gear. This means that a conducive economic, social, and political environment can make policy implementation successful in society, and vice versa. Current conditions, many fisherman demonstrations are politically charged so that the political environment is not conducive and can interfere with the successful implementation of cantrang fishing gear prohibition policies.

\section{CONCLUSION}

The perception of fisherman and government officers are not aligned in viewing and accepting policies so that it becomes the cause of the unsuccessful implementation of the prohibition of cantrang fishing gear in Lampung Bay. For fisherman, cantrang fishing gear is economically beneficial, considered to be non-degradative and destructive to the environment and fish resources. The government believes cantrang fishing gear threatens the preservation of fish resources and damages the aquatic environment. The implementation of the prohibition of cantrang fishing gear in Lampung Bay was unsuccessful due to the operation of cantrang vessels as a form of fisherman's rejection of the policy. Thus, it is necessary to review the policy of prohibiting fishing gear cantrang and strategic steps for its implementation.

\section{REFERENCES}

[1] R. Dahuri, Paragdima Baru Pembangunan Indonesia Berbasis Kelautan, Bogor, Institut Pertanian Bogor, 2003.

[2] A. Satria, Politik Kelautan dan Perikanan, Jakarta, Yayasan Pustaka Obor Indonesia, 2015. 
[3] M.R. Andryana, Strategi Adaptasi Nelayan dalam Menghadapi Peraturan Pelarangan Cantrang, Bogor, Institut Pertanian Bogor, 2016.

[4] E. Yapanani, A. Solichin, B.A. Wibowo, Kajian Hasil Tangkapan dan Tingkat Kesejahteraan Nelayan di Desa Aromarea Distrik Kosiwo, Kabupaten Sarui, Kepulauan Yapen, Papua, Journal of Management of Aquatic Resources, 2013, pp. 197-202.

[5] I.N. Aji, B.A Wibowo, Asriyanto, Analisis Faktor Produksi Hasil Tangkapan Alat Tangkap Cantrang di Pangkalan Pendaratan Ikan Bulu Kabupaten Tuban, Journal of Fisheries Resources Utilization Management and Technologi, 2013, pp. 50-58.

[6] A. Zamroni, Socio-Economics Status and Adaptations of Purse Seine Fishermen in Bali Coastal Village, Indonesia, International Journal of Marine Science, 2015, pp.1-16.

[7] W. Subani, H.R. Barus, Alat Penangkapan Ikan dan Udang Laut di Indonesia, Jakarta, Balai Penelitian dan Pengembangan Pertanian, 1989.

[8] N. Bambang, Petunjuk Pembuatan dan Pengoperasian Cantrang dan Rawai Dasar Pantai Utara Jawa Tengah, Semarang, Balai Besar Pengembangan Penangkapan Ikan, 2006.

[9] I.G. Febryano, J. Sinurat, M.L Salampessy, Social Relation between Businessman and Community in Management of Intensive Shrimp Pond, IOP Conference Series: Earth and Environmental Science, 2017, DOI: 10.1088/1755-1315/55/1/012042.

[10] I.G. Febryano, D. Suharjito, D. Darusman, C. Kusmana, A. Hidayat, The roles and sustainability of local institutions of mangrove management in Pahawang Island, Jurnal Manajemen Hutan Tropika, 2014, pp. 69-76.

[11] Y. Yuliasamaya, A. Darmawan, R. Hilmanto, Mangrove Forest Cover Change Along the Coast of East Lampung Regency, Jurnal Sylva Lestari, 2014, pp. 111

[12] D. Alfandi, R. Qurniati and I.G. Febryano, Community Participation in Mangrove Management, Jurnal Sylva Lestari, 2019, pp. 30.

[13] S.A. Wahab, Analisis Kebijakan: Dari Formulasi ke Penyusunan Model-Model Implementasi Kebijakan Publik, Jakarta, BumiAksara, 2012.

[14] H. Kartodihardjo, Analisis Kebijakan Pengelolaan Sumberdaya Alam, Bogor, Firdaus Pressindo, 2017.

[15] W.N Dunn, Pengantar Analisis Kebijakan Publik, Yogyakarta, Gadjah Mada University Press, 1991.

[16] D.G Myers, Sosial Psychology, New York, The McGrawHill Companies, Inc., 2013.

[17] Sugiyono, Metode Penelitian Kuantitatif Kualitatif dan $R \& D$, Bandung, Alfabeta, 2007. 